\title{
THE ROLE OF COLLABORATION VALUE CHAIN DESIGN AT REWARD-BASED CROWDFUNDING PLATFORMS AND MUSIC INDUSTRY IN INDONESIA
}

\author{
Octadila Laily Anggraeni ${ }^{*}$ and Elvia R. Shauki ${ }^{2}$ \\ ${ }^{1,2}$ Universitas Indonesia, Depok, Indonesia
}

\begin{abstract}
Industry 4.0 has brought many changes, in the financial sector there is financial technology. One form of financial technology is crowdfunding. Creative industries are quite high sectors that use crowdfunding as a funding model. This research includes collaboration between crowdfunding and the music industry. In the process of collaboration between the crowdfunding and the music industry, the parties need to conduct a value chain analysis and find out their competitive advantages to maximize fundraising. The consequence of collaboration between the crowdfunding and the music industry is the presence of new business models accompanied by changes in the value chain. This study aims to determine value chain design collaboration between reward-based crowdfunding and the music industry. This research is based on the value network theory, using a qualitative approach with multi-cases study design. This research was conducted by gathering information through interviews with crowdfunding and the music industry. The results show that collaboration leads to changes in value chain design. Crowdfunding has changed the pattern of production in the music industry with its involvement in funding, sales, and distribution. Other forms of crowdfunding and other creative industries require further investigation. This study aims to help practitioners understand how reward-based crowdfunding is changing the music industry.
\end{abstract}

Keywords: Music Industry, Reward-Based Crowdfunding, Value Chain

\section{INTRODUCTION}

The 4.0 industrial revolution has brought many conveniences in everyday life. Almost all activities are carried out with the help of the internet network (Ernst \& Young, 2018; Kagermann, H., Lukas, W., \& Wahlster, 2011; Marr, 2016). Ernst \& Young said that industrial revolution 4.0 was disruptive or destructive. In the era of industrial revolution 4.0, almost everything was forced to change from offline to online. Inter-human interaction has been replaced with the internet. All daily activities ranging from transportation, finance to shopping for daily necessities can be done quickly and easily with the internet.

In the financial sector, financial technology companies are growing rapidly. As of February 1, 2019, there are 99 financial technology platforms registered with OJK (Otoritas Jasa Keuangan, 2019). The forms of financial technology companies are also diverse but broadly speaking, Bank Indonesia categorizes financial technology into four major groups based on its activities, namely payment systems, market aggregators, investment and risk management, and loans, financing and capital provision. (Bank Indonesia, 2017). The first form is a payment gateaway that helps people make payments online. The second form is market support or market aggregator. The way the market aggregator works is to help users compare information on financial products and choose the one that suits their needs. Next is investment and risk management that helps in arranging financial planning digitally. The fourth form is loans, financing and provision of capital or commonly known as peer-to-peer lending and crowdfunding. Peer-to-peer lending has access to channel investor funds in the form of loans to microentrepreneurs (MSMEs) who find it difficult to apply for loans to banks. While crowdfunding serves to raise funds from the public for investment or social purposes.

* Corresponding author. Email address: octadilaily@yahoo.co.id 
(Paschen, 2017) divides crowdfunding into three groups: donations, loans, and capital. The crowdfunding typology described by Paschen is illustrated in Table 1 below:

Table 1. Crowdfunding Typology

\begin{tabular}{|c|c|c|c|c|c|c|c|}
\hline & \multicolumn{2}{|c|}{ Donation } & \multicolumn{3}{|c|}{ Loan } & \multicolumn{2}{|r|}{ Equity } \\
\hline & $\begin{array}{c}\text { Pure } \\
\text { Donation }\end{array}$ & Reward-based & $\begin{array}{c}\text { Forgivable } \\
\text { Loan }\end{array}$ & Presales & Traditi-onal & $\begin{array}{l}\text { Investor- } \\
\text { led }\end{array}$ & $\begin{array}{l}\text { Entrepreneur- } \\
\text { led }\end{array}$ \\
\hline \multicolumn{8}{|c|}{ without rewards $\longleftrightarrow$ With Rewards } \\
\hline Rewards & $\begin{array}{l}\text { Not } \\
\text { receiving } \\
\text { rewards }\end{array}$ & $\begin{array}{l}\text { Recognitions, } \\
\text { tokens, or } \\
\text { other rewards }\end{array}$ & $\begin{array}{c}\text { Interest, } \\
\text { only if the } \\
\text { project gets } \\
\text { income or } \\
\text { profits }\end{array}$ & $\begin{array}{c}\text { Finish } \\
\text { product } \\
\text { of project }\end{array}$ & $\begin{array}{c}\text { Fixed } \\
\text { interest rate }\end{array}$ & $\begin{array}{l}\text { Securities, } \\
\text { income, or } \\
\text { profit share }\end{array}$ & $\begin{array}{c}\text { Share of capital, } \\
\text { securities, } \\
\text { income, or } \\
\text { profit }\end{array}$ \\
\hline
\end{tabular}

Source: (Paschen, 2017)

(Badan Ekonomi Kreatif, 2016, 2017) mentions that crowdfunding can be one of the credible funding models for creative industries. The creative industry is a fairly high sector utilizing crowdfunding funding models. The report submitted by Kickstarter shows that music, film and games projects are projects that have been successfully funded with the most dollars. The total funds collected for the three projects are equivalent to $45 \%$ of the total projects registered on the Kickstarter (Kickstarter, 2019). In Indonesia, crowdfunding platforms that focus on handling creative industries, especially the art of music, is Kolase.com. The scope of this research is only on crowdfunding platform collaboration and the music industry.

Rapid technological developments have triggered changing customer tastes and uncertain competition. On the other hand, there is a niche market because customers seek customization and taste to satisfy their individual preferences (Russ, Kuilboer, \& Ashrafi, 2014). In such challenging environments, companies must have a competitive advantage to survive. Competitive advantage cannot be understood by looking at the company as a whole (Porter, 1995). Porter introduces value chains as a tool that helps companies better recognize their competitive advantage and facilitate strategy determination.

In the process of collaboration between crowdfunding platforms and the music industry, the culprit needs to do value chain analysis and find out its competitive advantages to maximize collection of funding. (Nucciarelli et al., 2017) explained the consequences of the collaboration was the existence of a new business model accompanied by changes in the value chain that had an impact on the relationship between developers and other industry stakeholders. The collaboration value chain between crowdfunding platforms and the music industry is different from their respective value chains. This research was conducted to find out the value chain design collaboration between crowdfunding platforms and the music industry. Collaborative value chain design can then be used by musicians to maximize the value creation process in the results.

Previous research conducted by (Hadida \& Paris, 2014) on managerial changes in the music industry shows that the digital music industry has strengthened their value chains better than the traditional music industry. The cognitive framework of the value chain can influence investor interpretation of the digital music industry. (Hadida \& Paris, 2014) research has not included collaborative elements between technology and the music industry. 
(Gamble, Brennan, \& McAdam, 2017; Pastonesi, 2013) conducted an exploratory study on how reward-based crowdfunding affected the development of the music industry. Crowdfunding also contributes to marketing and brings musicians closer to their listeners. Crowdfunding finally succeeded in becoming a solution for musicians to obtain funding sources for production activities and provide greater control than when musicians worked with record companies. Both studies have not included the value chain element. Research conducted by (Nucciarelli et al., 2017) has combined elements from previous research to find out the effect of reward-based crowdfunding on the process of creating value in the digital game industry. This study replicates (Nucciarelli et al., 2017) research with different objects, locations and times of research.

This research is based on value network theory, using a qualitative approach with the design of multi cases studies. The design of multi-case studies studies helps in observing the similarities and differences of each case studied (Stake, 2006). This research helps to observe the value chain transformation that is created from the collaboration of reward-based crowdfunding platform with music industry. This research is expected to help practitioners understand the collaboration value chain between the value chain platform and the music industry so they can find out their competitive advantages.

The research is organized as follows: part 1 discusses background and research problems, section 2 contains a literature review of crowdfunding and the theory underlying the research, section 3 discusses the design and research methods in detail, section 4 contains the results of music industry analysis and value chain transformation created by the collaboration of the music industry with reward-based crowdfunding, and section 5 contains conclusions and suggestions for future research.

\section{LITERATURE REVIEW}

Value network theory is introduced by (Stabell \& Fjeldstad, 1998). Stabell and Fjelstad explained that the value creation process allows exchanges in networks with scales and compositions that are in accordance with the needs of members. Value networks emphasize that values are created when interactions are facilitated by value networks.

The value chain was first introduced by Porter in 1995. (Porter, 1995) defines value chain as a series of processes carried out by companies to identify key activities and supporting activities related to value creation. Value chain is an ideal framework to examine how the value proposition works, the cost structure and the business model of the company.

Value proposition is the reason for customers to choose a product. The process of creating this value can be maximized through value chain analysis (Thompson, Strickland III, Gamble, \& Peteraf, 2017). The higher the value proposition of a product, the higher the customer's willingness to get the product.

In the value chain, company activities are divided into two groups, namely the main activities and supporting activities. The following is a description of the relationship between the main activities and supporting activities in the value chain: 
AFEBI Management and Business Review (AMBR)

Vol.04 No.01, June 2019

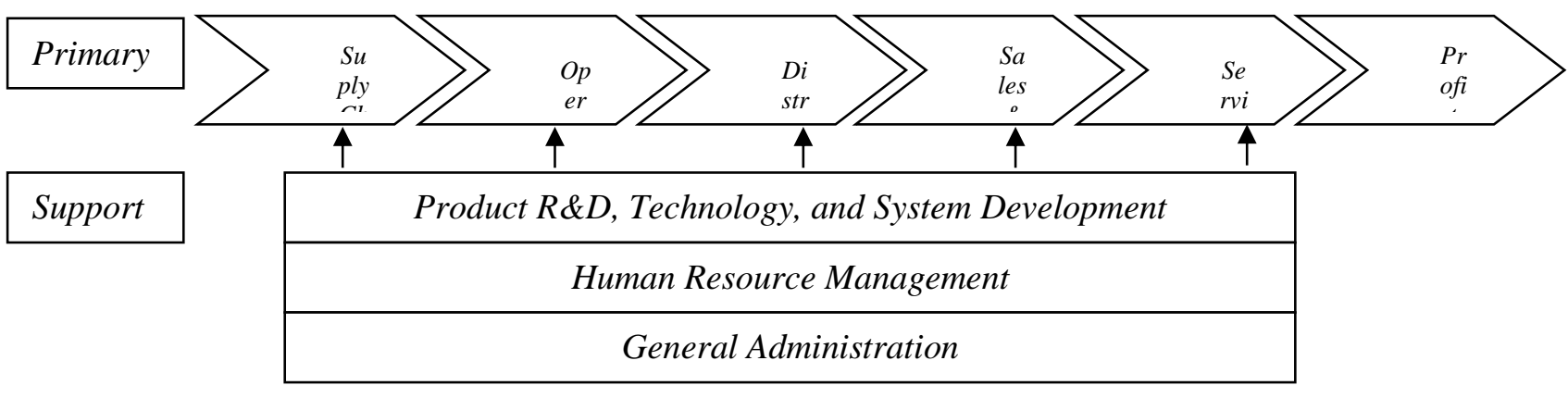

Figure 1 Value chain

Source: (Thompson et al., 2017)

Basically the value chain is formed by the activities mentioned above, but the activities involved will vary according to the peculiarities of each business model. Through the value chain, companies can conduct an analysis of the company's cost structure, the value creation process, and conduct evaluations so that the company can act effectively in accordance with its competitive advantage.

(Hadida \& Paris, 2014) research shows that there has been a change in the value chain design in the music industry when it changes from traditional to digital. The cognitive framework of the value chain can influence investor interpretation of the digital music industry. (Hadida \& Paris, 2014) research has not included collaborative elements between technology and the music industry. This study aims to fill the research gap.

(Bank Indonesia, 2017) defines financial technology as the use of technology in the financial system to provide services, products or new business models. The phenomenon of financial technology is relatively new in Indonesia and Bank Indonesia only regulates this industry in 2017. In the regulations issued by Bank Indonesia, the financial technology industry is divided into four groups: payment gateaway, market support, investment and risk management, and crowdfunding and peer-to-peer lending. The financial technology industry is growing rapidly and as of January 2019 there have been 192 financial technology companies consisting of 161 start-up companies, 22 financial institutions and 9 associate partners (Fintech Indonesia, 2019).

One form of financial technology is crowdfunding. (Kirby \& Worner, 2014) in his report explains that crowdfunding is a sum of funds collected by large groups of individuals or groups to fund business or personal projects through web-based platforms. (Kirby \& Worner, 2014) then explained that there are four crowdfunding categories, namely donations, reward-based, loans and capital. It was different with (Paschen, 2017) which divides crowdfunding into three major groups, namely those that are donations, loans, and capital. Paschen also categorizes crowdfunding based on the rewards earned. The crowdfunding typology delivered by (Paschen, 2017) is explained in Table 1.

(Paschen, 2017) divides crowdfunding types of donations into two groups, which are pure donations and reward-based. When doing reward-based crowdfunding organizations or groups that need funds will offer a return to the owner of the funds in the form of goods or services from the project or work carried out. Reward-based crowdfunding is very popularly used in the creative industry and usually the rewards given to the owner of the fund are in the form of work produced. One of the rewardbased crowdfunding platforms in Indonesia is Kolase.com. Until February 2019, Kolase.com has successfully funded 54 projects and collected Rp1.1 billion. (Kolase.com, 2019)

Research conducted by (Gamble et al., 2017; Pastonesi, 2013) shows that crowdfunding is able to bring musicians closer to their listeners. Crowdfunding is also able to be a solution for musicians to obtain funding sources for production activities 
and provide greater control than when musicians collaborate with record companies. Both studies have not included the element of value chain analysis.

Subsequent research conducted by (Nucciarelli et al., 2017) in the gaming industry has integrated value chain logic and collaboration between crowdfunding platforms and the gaming industry. Nucciarelli et al. (2017) found that crowdfunding is not only for raising funds but also bringing together capital, technology and market knowledge channels. The findings also explain the effects of crowdfunding on the gaming industry.

This research was carried out on collaboration between reward-based crowdfunding platforms and the music industry in Indonesia. Filling in the gap of research conducted by Gamble et al. (2017) and Pastonesi (2013), this study integrates the collaboration with the value chain logic so that an overview of collaboration value chain design can be obtained.

This research was formulated through the following research framework:

Value network theory (Stabell \& Fjeldstad, 1998)

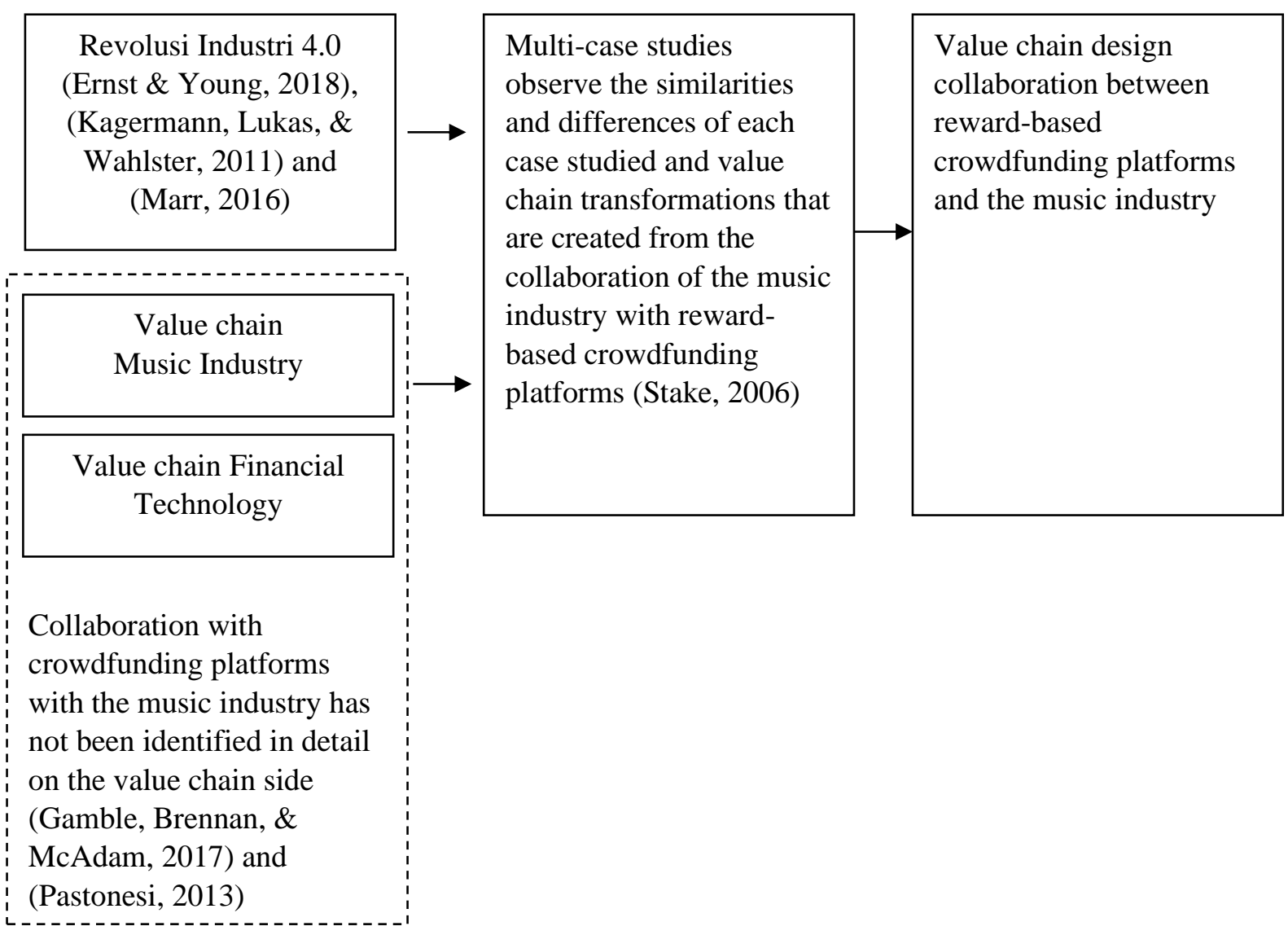

Figure 2 Research Framework

This study aims to produce a value chain design collaboration between rewardbased crowdfunding platforms and the music industry to help understand the structure of the new value chain formed from the collaboration. This research is based on value network theory, in this study the music industry and all parties involved in crowdfunding platforms are positioned as members of the value network. This research was conducted with a multi cases studies strategy to find the similarities and differences in each funding case on crowdfunding platforms to find out the collaboration effects that were generated. 


\section{RESEARCH METHODOLOGY}

This research was conducted to find out the new value chain design created from the collaboration process of reward-based crowdfunding platforms with the music industry in Indonesia. In this chapter we discuss the strategy, and the research approach used, data collection and analysis methods, and the unit of analysis used in this study.

(Yin, 2003) defines case studies as research methods that explain how a phenomenon occurs. Whereas (Stake, 2006) defines a case study as a research method used to determine the unique characteristics of each case. Stake also explained that in case studies it was necessary to extract information and in-depth analysis of a case. Based on the understanding of the case study, this study uses a case study research strategy because it aims to gain a deep understanding of the phenomenon of crowdfunding platform collaboration with the music industry.

(Stake, 2006) explains that there are two types of case studies, namely single case studies and multi cases studies. The difference is in multi cases studies, the number of cases observed is more than one with the same procedure and analyzed together. This study analyzes the interaction of several music collaboration projects with rewardbased crowdfunding platforms in value creation so that the strategies used are multi cases studies.

This study uses a qualitative approach. Yvonna and Egon Guba (1985) in (Stake, 2006) show that qualitative research is based on the view that social phenomena, social dilemmas and the nature of cases are situational. A case study with a qualitative approach was developed to study the real case experience that actually happened.

This study uses qualitative data, namely data in the form of words such as notes on the results of interviews, transcripts, and open statements on the internet. Qualitative data analysis is intended to make valid conclusions from the amount of data collected (Sekaran, U., \& Bougie, 2016). In this study, the data used were only qualitative data obtained from interviews with reward-based crowdfunding platforms and music industry collaborators with crowdfunding platforms.

The data used in this study are primary data. Primary data is data collected by researchers directly for specific research purposes (Sekaran, U., \& Bougie, 2016). Primary data was obtained from speakers on reward-based crowdfunding platforms and music industry collaborators with crowdfunding platforms.

There are four main methods to obtain primary data, namely interviews, observations, questionnaires and experiments (Sekaran, U., \& Bougie, 2016). This study uses research instruments in the form of semi-structured interviews and content analysis. Semi-structured interviews are used to gain an in-depth understanding of the phenomena that occur with a guide to the list of questions that have been prepared previously aimed at answering research problems. The semi-structured interview model makes the interview more flexible so that the information explored becomes deeper.

Semi-structured interview questions were designed to gather data about the overall crowdfunding process from production input, marketing, to distribution to customers, both from crowdfunding platforms and musician platforms as campaigners. The interview results are then grouped according to the associated value chain stages so that it is known that the collaborative value chain design is formed.

In addition to interviews, another research instrument that is also used is content analysis. Kolbe \& Burnett in (Sekaran, U., \& Bougie, 2016) defines content analysis as observational research methods used to evaluate systematically the content of all forms of communication are recorded. The results of the interviews collected in this study was analyzed using content analysis.

The data analysis method used in this study is content analysis. Content analysis can be used to analyze newspapers, websites, advertisements, interview records, and the like. Content analysis allows this research to analyze text information and systematically identify its properties, such as the existence of certain words, concepts, characters, themes, or sentences (Sekaran, U., \& Bougie, 2016). 
Data from the interviews was obtained, it was then analyzed by grouping them according to the type and context of the information obtained. First of all, two large groups were created, namely the results of interviews from the crowdfunding platform based on rewards and the results of interviews from each selected music project. Furthermore, the results of selected music project interviews were grouped again according to the nature and type of project. In this study five music album-making projects were selected.

The unit of analysis in this study is multi unit analysis. The object of the research in question is a reward-based crowdfunding platform and music projects that collaborate with crowdfunding platforms. The intended reward-based crowdfunding platform is Kolase.com, an online joint venture formed by PT Kirai Adiwarna Nusantara (KAWAN). Kolase.com is currently the only reward-based crowdfunding platform that specifically handles music collaboration projects. Kolase.com bridges musicians with their fans and also the owners of funds who want to channel their funds to support music projects made by musicians. Forms of music projects that can be made can be various, ranging from making albums, tours, to music concerts. Since its launch on February 1, 2018, Kolase.com has succeeded in realizing 54 collaborations and collecting Rp1.1 billion in rupiah at the end of February 2019. 54 collaboration projects consist of various types of collaboration categories. Kolase.com also has 20,267 members joined (Kolase.com, 2019). Every customer who donates to an art project on Kolase.com must be registered as a member.

The other unit of analysis is music projects resulting from collaboration between Kolase.com and musicians. The type of music project chosen is the making of an album because it is more complex and represents the condition of the music industry as a whole, from production to music to customers. Since its launch, there have been 11 album-making projects and five of them have been completed. This research selects five album collaboration collaborative projects that have been completed to be analyzed further on collaboration value chain images formed from the reward-based crowdfunding platform (Kolase.com) and the music projects. In the discussion, musicians were referred to as campaigners or those who make campaigns on crowdfunding platforms.

\section{RESULTS}

This section discusses the analysis of research results including the general description of research respondents, and the process of obtaining data. The discussion was then conducted in accordance with the research objectives, namely value chain design on crowdfunding platforms, value chain design in the music industry, and collaborative value chain design generated in the crowdfunding process.

Interviews in this study were conducted on crowdfunding platform Kolase.com and campaigners on album-making projects. As of March 1, 2019, there were five albummaking projects that were successfully funded and all were targeted by respondents.

In conducting the research, interviews were only successfully carried out on crowdfunding platform management and three of the five targeted campaigners due to limited access and time of research. The response rate that was collected for the campaigners was $60 \%$. All access to interviews with campaigners is obtained from crowdfunding platforms Kolase.com.

Based on the information gathered during the interview with the crowdfunding platform, information was obtained that basically kolase.com is only a platform whose task is to raise funds from customers to realize the work of campaigned musicians. The workings of crowdfunding platforms are basically the same as other internet-based platforms such as social media, where campaigners can directly create their projects on the Kolase.com webpage. But in practice, campaigners still need assistance to compile any information that needs to be published on the kolase.com page to appeal to prospective customers. Furthermore, in the production process, the entire creative 
process is fully handed over to musicians but in the process of making merchandise some musicians request advice on the form of merchandise and funding packages that are in accordance with the profile of customers who follow crowdfunding.

Kolase.com helps campaigners promote their work through social media, press releases, and making promotional material in the form of photos and videos. For the distribution process, Kolase.com has collaborated with freight forwarders that are integrated with the platform. This makes it easier for campaigners to distribute their work to customers and minimize the risk of shipping errors. After the campaign was completed, kolase.com sent out customers database who joined crowdfunding to the campaigner. This database contains information such as gender, age and area of origin of the customer.

Kolase.com also provides a polling feature that can be utilized by campaigns to conduct research before making a senior project. Information that can be polled such as the location of the concert, guest stars of art events, choice of album covers, or the price of merchandise to be made. This feature helps the campaign to conduct research on the market to be targeted.

Based on the information collected during interviews with music industry players, information about the value chain description in the music industry is obtained in the following Table 2 .

Table 2 Results of interviews with campaigners.

\begin{tabular}{|c|c|c|c|}
\hline \multirow{2}{*}{$\begin{array}{l}\text { Value chain } \\
\text { Funding }\end{array}$} & Eirine & Dekat & ElephantKind \\
\hline & $\begin{array}{l}100 \% \text { funding from } \\
\text { Crowdfunding }\end{array}$ & $\begin{array}{l}\text { Album production costs: own } \\
\text { costs } \\
\text { The physical production cost of } \\
\text { the album from Crowdfunding } \\
\text { on Kolase.com }\end{array}$ & $\begin{array}{l}\text { Album production costs: own } \\
\text { costs } \\
\text { The physical production cost of } \\
\text { the album from Crowdfunding } \\
\text { on Kolase.com }\end{array}$ \\
\hline $\begin{array}{l}\text { Development \& } \\
\text { Production }\end{array}$ & $\begin{array}{l}\text { The entire creative } \\
\text { process of the } \\
\text { album } \\
\text { merchandise is } \\
\text { done by itself }\end{array}$ & $\begin{array}{l}\text { The entire creative process of the } \\
\text { album and merchandise is done } \\
\text { by itself }\end{array}$ & $\begin{array}{l}\text { The entire creative process of the } \\
\text { album and merchandise is done } \\
\text { by itself }\end{array}$ \\
\hline $\begin{array}{l}\text { Sales } \\
\text { Marketing }\end{array}$ & $\begin{array}{l}\text { Kolase.com } \\
\text { provides } \\
\text { promotional } \\
\text { material in the form } \\
\text { of photos and } \\
\text { videos. }\end{array}$ & $\begin{array}{l}\text { Kolase.com provides } \\
\text { promotional material in the form } \\
\text { of photos, videos and press } \\
\text { releases. Kolase.com sends blast } \\
\text { emails related to album projects } \\
\text { to all its members. }\end{array}$ & $\begin{array}{l}\text { Kolase.com provides } \\
\text { promotional material in the form } \\
\text { of photos, videos and press } \\
\text { releases. Kolase.com sends blast } \\
\text { emails related to album projects } \\
\text { to all its members. }\end{array}$ \\
\hline Distribution & $\begin{array}{l}\text { The distribution } \\
\text { process is carried } \\
\text { out by the band } \\
\text { itself }\end{array}$ & $\begin{array}{l}\text { The distribution process is } \\
\text { carried out by JNE which is } \\
\text { integrated with Kolase.com }\end{array}$ & $\begin{array}{l}\text { The distribution process is } \\
\text { carried out by JNE which is } \\
\text { integrated with Kolase.com }\end{array}$ \\
\hline Market & $\begin{array}{l}\text { DVDs and } \\
\text { merchandise } \\
\text { tailored to customer } \\
\text { profiles. After } \\
\text { crowdfunding is } \\
\text { complete, } \\
\text { Kolase.com hands } \\
\text { over the customer } \\
\text { database. }\end{array}$ & $\begin{array}{l}\text { DVDs and merchandise } \\
\text { produced are limited only to } \\
\text { customers who follow } \\
\text { crowdfunding. } \\
\text { After crowdfunding is complete, } \\
\text { Kolase.com submits a customer } \\
\text { database that can be used to plan } \\
\text { the next work. }\end{array}$ & $\begin{array}{l}\text { DVDs produced are limited to } \\
\text { customers who follow } \\
\text { crowdfunding. } \\
\text { Merchandise is made costumized } \\
\text { for each customer. } \\
\text { After crowdfunding is complete, } \\
\text { Kolase.com submits a customer } \\
\text { database that can be used to plan } \\
\text { the next work. }\end{array}$ \\
\hline
\end{tabular}

Based on the information gathered during the interview with the campaigner, it shows that crowdfunding is not limited to fundraising but also influences other 
components of the value chain and changes the campaigner's working pattern in producing works. At least there are five components of the value chain in the main activities that change. First, in terms of campaigner funding, new funding sources are obtained from customers who follow crowdfunding. This was confirmed in the Eirine case where all costs for production were obtained from crowdfunding. Second is the polling feature on crowdfunding platforms that campaigners can use to research prospective customers' tastes before making a work. This feature is known by the campaigner but has not been utilized because each campaigner has a mature concept. Third, in terms of sales and marketing, crowdfunding platforms help campaigners in preparing promotional materials for prospective customers. The market reach that can be achieved by campaigners is broader with the promotion assistance from crowdfunding platforms through press releases to its members via e-mail and promotions through social media and electronic media. Fourth, from a crowdfunding platform distribution side, it really helps campaigners to send their work to customers because the system on crowdfunding platforms has been integrated with the logistics company system. The facility is felt by the Dekat and ElephantKind, while at Eirine crowdfunding, the system has not been integrated. The fifth is from the market side. After the project is done, the crowdfunding platform sent out a project report to the campaigner. The report is the database of the customers participating in the project made. Information submitted includes customer gender, age, region, and social media.

\section{DISCUSSION}

\section{Collaborative Value Chain Design in Reward-based Crowdfunding Platform and} Music Industry in Indonesia

This study aims to produce collaborative value chain designs between crowdfunding platforms and the music industry during crowdfunding. The framework design proposed in this study is illustrated in Figure 3 below:

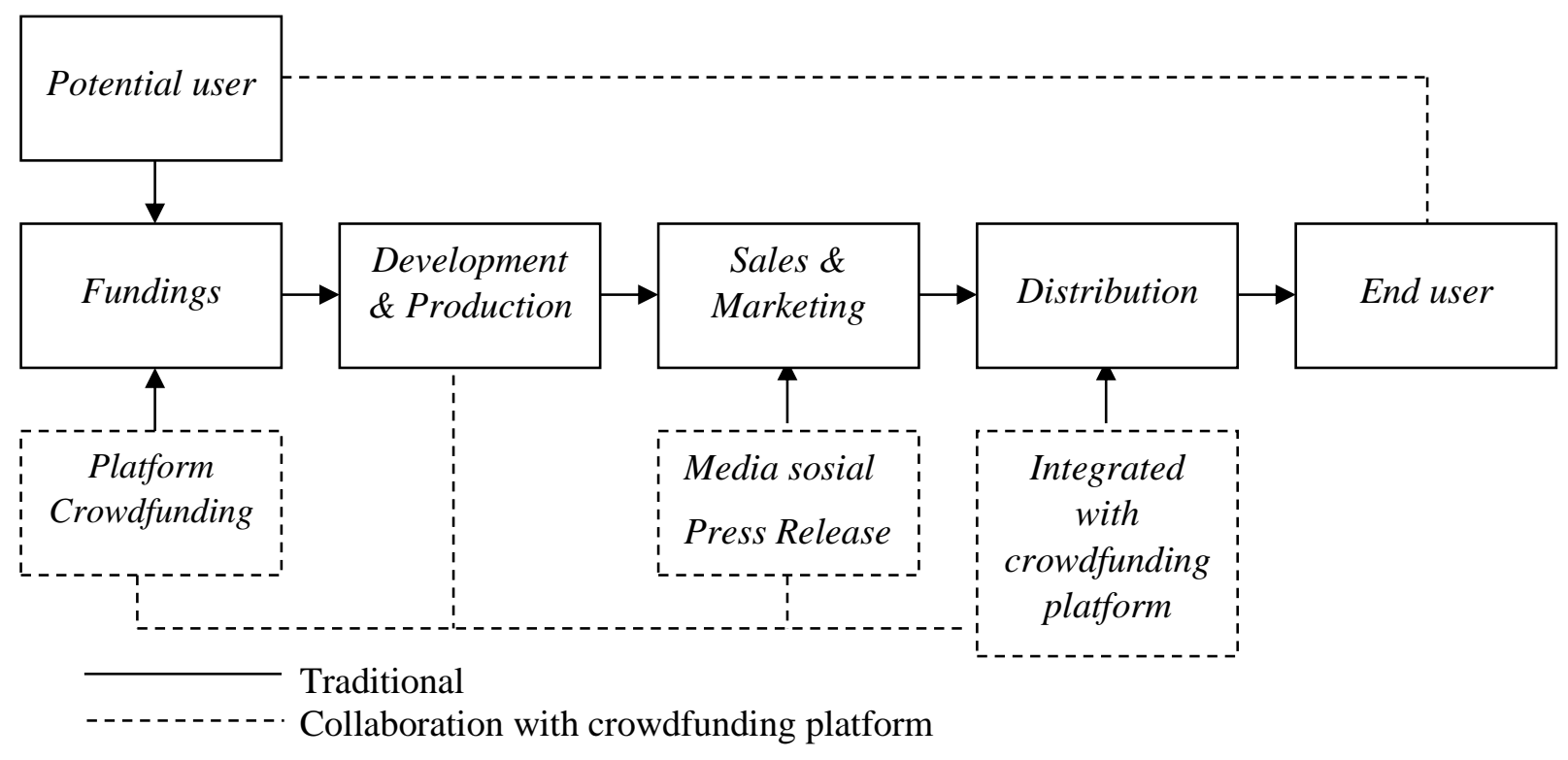

Figure 3 Collaborative Value Chain Design

This research uses the value chain logic to analyze value creation in the collaborative process between crowdfunding platforms and the music industry. The results of the study show that crowdfunding has brought changes to the music industry. The process of creating value has undergone many changes. In the main activity illustrated in Figure 3, it is known that all components of the value chain have collaborated in creating value between crowdfunding platforms and the music industry. At the funding stage, campaigners obtain new funding sources from crowdfunding. 
Later in the product development stage, campaigners can take advantage of the research facilities provided by crowdfunding platforms. At the stage of selling and distributing products to campaigner customers, it is quite helpful to have integration between crowdfunding platforms and logistics companies. Campaigners also obtain customer databases at the end of the project period. The collaboration value chain design above helps campaigners to analyze competitive power and value creation from the collaboration process that is formed.

In terms of value network theory, value creation is formed from the interaction of campaigners and customers through crowdfunding projects. Interaction that occurs is that customers pay their funds to campaigners through crowdfunding platforms, and campaigners send products to customers based on data processed by crowdfunding platforms. All parties involved in the crowdfunding process show interdependence in the value creation process.

\section{CONCLUSION}

This section summarizes the results of the research described in the previous section, explain the limitations of the study, and provide suggestions for subsequent research.

This research aims to find out value chain design as a result of collaboration between crowdfunding platforms and the music industry in Indonesia. Research found that the collaboration process occurs in almost all the main activities in the value chain. Crowdfunding indirectly has changed the pattern of production in the music industry in Indonesia with its involvement in funding, product development, sales, distribution, until the product reaches the customer's hands. The role of crowdfunding platforms as a means of interaction between campaigners and their customers in value creation is a form of value network application theory.

Time constraint has limited the author to gather more responses, though response rate is equal to $60 \%$, this can be improved by extending the period of study. In addition, this study only analyzes album-making projects, while there are other forms of projects that can be found in the music industry.

The proposal for further research is to increase the number of respondents to the study and the types of projects analyzed in order to obtain a broader and more varied picture of collaboration between crowdfunding platforms and the music industry in Indonesia. In addition, research can be carried out regarding the effects of crowdfunding on entrepreneurial decisions in the creative industry. The research allows researchers to understand the effects of social capital on crowdfunding project design.

\section{References}

Badan Ekonomi Kreatif. (2016). Mengenal Crowdfunding. Retrieved February 28, 2019, from http://indonesiakreatif.bekraf.go.id/ikpro/financials/mengenalcrowdfunding/

Badan Ekonomi Kreatif. (2017). Ekonomi Kreatif Outlook 2017: Era Ekonomi Kreatif harus menjadi tulang punggung ekonomi Indonesia, 82.

Bank Indonesia. (2017). Peraturan Bank Indonesia Nomor 19/2/PBI/2017, (Tentang Transaksi Sertifikat Deposito di Pasar Uang). Retrieved from http://www.bi.go.id/id/peraturan/moneter/Documents/PBI_190217.pdf

Ernst \& Young. (2018). Industry 4.9: engaging with disruption. Ahmedabad.

Fintech Indonesia. (2019). Fintech Indonesia. Retrieved February 20, 2019, from https://fintech.id/

Gamble, J. R., Brennan, M., \& McAdam, R. (2017). A rewarding experience? Exploring how crowdfunding is affecting music industry business models. Journal 
of Business Research, 70, 25-36. https://doi.org/10.1016/j.jbusres.2016.07.009

Hadida, A. L., \& Paris, T. (2014). Technological Forecasting \& Social Change Managerial cognition and the value chain in the digital music industry. Technological Forecasting \& Social Change, 83, 84-97. https://doi.org/10.1016/j.techfore.2013.04.005

Kagermann, H., Lukas, W., \& Wahlster, W. (2011). Industry 4.0: With the Internet of Things on the way to the 4th industrial revolution. vdi-nachrichten.

Kickstarter. (2019). Successfully Funded Projects. Retrieved February 10, 2019, from https://www.kickstarter.com/help/stats

Kirby, E., \& Worner, S. (2014). Crowdfunding: An infant industry growing fast. IOSCO Research Department, 1-62. https://doi.org/10.1037/0893-164x.19.2.208

Kolase.com. (2019). Kolase.com. Retrieved February 20, 2019, from https://www.kolase.com/

Marr, B. (2016). Why Everyone Must Get Ready For The 4th Industrial Revolution. Retrieved February 20, 2019, from https://www.forbes.com/sites/bernardmarr/2016/04/05/why-everyone-must-getready-for-4th-industrial-revolution/\#5af877b33f90

Nucciarelli, A., Li, F., Fernandes, K. J., Goumagias, N., Cabras, I., Devlin, S., ... Cowling, P. (2017). From value chains to technological platforms: The effects of crowdfunding in the digital game industry. Journal of Business Research, 78, 341352. https://doi.org/10.1016/j.jbusres.2016.12.030

Otoritas Jasa Keuangan. (2019). Penyelenggara Fintech Terdaftar di OJK per 1 Februari 2019.

Paschen, J. (2017). Choose wisely : Crowdfunding through the stages of the startup life cycle. Business Horizons, 60(2), 179-188. https://doi.org/10.1016/j.bushor.2016.11.003

Pastonesi, R. (2013). The impact of crowdfunding on musicians' business: Findings from Denmark, Norway, and Sweden. Retrieved from https://repositorio.ucp.pt/bitstream/10400.14/14071/1/Master Thesis Rocco Pastonesi.pdf

Porter, M. (1995). Competitive Advantage: Creating and Sustaining Superior Performance. New York: Free Press.

Russ, H., Kuilboer, J.-P., \& Ashrafi, N. (2014). Business Intelligence in the Music Industry Value Chain: Ensuring Sustainability in a Turbulent Business Environment. International Journal of Business Intelligence Researchgence Research, 5(1), 50-63. https://doi.org/10.4018/ijbir.2014010104

Sekaran, U., \& Bougie, R. (2016). Research Methods for Business: A Skill-Building Approach (7th Editio). New Jersey: John Wiley \& Sons Ltd.

Stabell, C. B., \& Fjeldstad, Ø. D. (1998). Configuring value for competitive advantage: on chains, shops, and networks. Strategic Management Journal, 19(5), 413-437. https://doi.org/10.1002/(sici)1097-0266(199805)19:5<413::aid-smj946>3.3.co;2$\underline{3}$

Stake, R. E. (2006). Multiple Case Study Analysis THE GUILFORD PRESS New York London.

Thompson, A., Strickland III, A. J., Gamble, J. E., \& Peteraf, M. A. (2017). Crafting 
AFEBI Management and Business Review (AMBR)

Vol.04 No.01, June 2019

and Executing Strategy. The Quest For Competetive Advantage: Concepts.

Yin, R. K. (2003). Application of Case Study Research Second Edition. Interpretive Interactionism (2nd Edition). California: Sage Publication. 